\title{
A Note on Public Sector's Corruption Equilibrium and Network
} Economy

\author{
Yaron Zelekha ${ }^{1}$ \\ ${ }^{1}$ Faculty of Business Administration, Ono Academic College, Kiryat Ono, Israel \\ Correspondence: Yaron Zelekha, Faculty of Business Administration, Ono Academic College, Kiryat Ono, 14 \\ Hagaon Eliyahu st., Ramat Gan, Israel. Tel: 97-250-690-9000. E-mail: yaronzl@013.net.il
}

Received: April 5, 2013 Accepted: May 2, 2013 Online Published: September 30, 2013

doi:10.5539/par.v2n2p185 URL: http://dx.doi.org/10.5539/par.v2n2p185

\begin{abstract}
Most of the studies on Public Sector's corruption focused on the micro economic aspects of the criminal behavior and only limited research has conducted on the macro level in general and market equilibrium in particular. In an attempt to better understand the phenomenon of corruption this paper uniquely analyzes corruption in view of the 'network economy' theory and suggests a theoretical framework for understanding corruption equilibrium. I claim that corruption reaches equilibrium under two extremes which make it difficult for countries to move from one to the other. Unfortunately, it is thus almost impossible for a country to make a significant transition on its own and the chances of gradual reforms are generally not very good.
\end{abstract}

Keywords: Corruption, Network Economy, equilibrium

JEL: K0, E69

\section{Introduction}

A well-known story describing public sector's corruption and its effect on society is attributed to Tiberius Caesar, as documented by Cornelius Tacitus, the senator and famous historian of the Roman Empire, in his great work The Annals. According to Tacitus, the Senate of Rome decided to grant a large sum of money to an established family that had served the Senate for many years. The reason behind the Senate decision was the inconvenient situation the family faced: due to personal business losses, the family risked forfeiting its seat in the Senate in the nearest census. Because of these losses, the family would not reach the minimum equity threshold necessary to hold a Senate seat without a grant. When Tiberius Caesar heard about the Senate's decision, he rushed to the Senate and "convinced" the Senators to cancel the grant, claiming that an authority that distributes the public treasury to its friends is essentially unjust. After the Senate annulled the grant, Tiberius Caesar announced that he would provide that family a personal grant, allowing the family to meet the equity threshold and keep the Senate seat.

Public sector's corruption exists in all countries, both developed and developing. Moreover, corruption in public institutions is generally perceived to have become structured and well-established, involving well-organized networks. Rose-Ackerman (1999) explains that corruption is usually carried out in networks where trust and reciprocity exist among its members. From an economic perspective, network ties reduce transaction costs and can enables corrupt transactions.

The motives for illegal activity (in its many forms, such as corruption) and its effect on society have been studied extensively in the social sciences and criminology. However, only in the late 1960s did economists begin to study this issue (see Becker, 1968; Stigler, 1970; and Ehrlich, 1973). These and other researchers demonstrated that economic theory can provide important insights into criminal behavior and can contribute to the theoretical analysis of its impact on the economy and on society as a whole.

The research of public-sector corruption has received growing attention in recent years. Macrae (1982) defines corruption as an arrangement that involves a private exchange between two parties, which (1) influences the allocation of resources either immediately or in the future, and (2) involves the use or abuse of public or collective responsibility for private ends (see also Bardhan, 1997).

However, most of the studies focused on the micro economic aspects of the criminal behavior and only limited research has conducted on the macro level in general and market equilibrium in particular. 
In an attempt to better understand the phenomenon of corruption this paper uniquely analyzes corruption in view of the 'network economy' theory and suggests a theoretical framework for understanding corruption equilibrium.

\section{Theory}

Zelekha and Bar-Efrat (2011) suggested in an empirical research examining the effect of crime on private investment in Israel that crime and corruption has the characteristics of a network economy. In these framework fixers, fostering corruption, play the role of a two sided platform/service supplier in a network environment.

In such a situation, a supplier of a mediator platform (like a cellular network) or service (like a matchmaker) gains power as a direct result of the number of customers he manages to attract on either side of the platform/service. The more customers he has, the stronger he will be and the more able he will be to attract additional customers on both sides. In other words, the supplier's strength is based not only on endogenous factors, such as an efficient production process or superior labeling, but on an exogenous factors as well, i.e. the number of his customers relative to his competitors'.

Essentially, every additional customer creates the potential for the next one as part of a never-ending cycle that benefits the supplier but is liable to be to the disadvantage of his customers. As the supplier becomes more powerful, his service of mediation becomes essential so he can allow himself to increase his profits at the expense of his customers, which in turn causes increasing harm to economic welfare. For example, regarding fixers, as the fixer recruits more firms or citizens who needs his mediation services, the more able he is to offer public servants favors, and vice versa. The two sided platform becomes an institutionalized system for the exchange of favors among those in authority.

Furthermore, in the absence of an efficient regulator, or checks and balances, the supplier will become a monopoly in his field of activity (whether it is a specific municipality or government office) or at least a supplier with disproportionate power over his customers. Alternatively, if the supplier does not manage to reach a critical mass of power, he is destined to disappear.

\section{Discussion}

The simple fact that lies behind any discussion about the origins of corruption is that there is no corruption without corruptive agents, a beneficial good (product, service or asset) and an action, whether active or passive. Since government is the biggest agent of all, not to mention the largest economic entity, most research in the economic literature is dedicated to public corruption. Government officials have the authority to redistribute resources, such as tax incentives, subsidies, privatization of assets or granting of licenses (including anti-trust licenses for mergers and acquisitions) to specific sectors or entities. However, this authority can be exploited for personal gains. In theory, the greater the degree of discretion that is given to government officials, the more opportunities there will be for them to demand a bribe in exchange for offering favorable treatment. For an extensive review on the origins of corruption see Zelekha (2103).

Corruption can be seen therefore as a market transaction cost which occurs when public officials have non-transparent discretionary power (often due to weak institutional constraints) to extract rents from those seeking governmental services, such as licenses and permits. The lack of transparency, which creates imperfect information between the public official and the public, can be a result of two alternatives:

First, non-transparent government decisions and licenses. For example, until 2006 the government of Israel never published the waivers from tenders issued by the Accountant General. Under this hidden framework, numerous illegal waivers were given, mostly to major business corporations and to government companies run by political strongmen. Only in 2006 did I decide, as the Accountant General of Israel, to publish in real time all the waiver decisions, including the reasons behind them. As Justice Louis Brandeis famously said, "Sunlight is said to be the best of disinfectants".

Second, non-comparable government decisions and licenses, such as soft anti-trust rulings for mergers and acquisitions or a soft approach of capital market regulators towards public companies. Naturally, since every market is different and difficult to compare, every decision can be somehow justified.

It should be stressed that corruption can establish a (black) market mechanism by which the agent (the official) creates a market of escalating bribes such that the service-seekers (the agents) most in need bid the most in bribes and get the services first.

Garson (2007) claims that corrupt agents may supply government services to maximize bribes, instead of maximizing service delivery. Unlike open auctions, inefficiencies in service allocation under corruption may also arise from the expenditure of resources to keep corrupt deals secret. Moreover, the collection of rents accrues to 
the agent, not to the government (the principal), and these revenues are unavailable for reinvestment in more efficient means of service delivery. In the case of corrupt tax officials, government revenues may be reduced considerably. Also, corrupt officials may take steps to assure the continued inefficiency of "normal" service delivery precisely so that citizens must use bribes to obtain needed services. Then, from the citizens' point of view, corrupt deals lack security because contracts cannot be enforced in courts, and lack of security impedes efficient planning by entrepreneurs. For the principal (government or public) to regain control over the agent (the corrupt official), monitoring/enforcement must be increased and salaries of officials must be raised to the point where fear of dismissal outweighs hope for profit through bribery. However, costs of monitoring and costs of higher salaries may prove to be great enough to actually reduce overall government revenues in comparison with relying on low-paid, corrupt agents.

Shleifer and Vishny (1998) assume that all government officials will be corrupt, given the opportunity. Moreover, they hold that governments adopt economic policies with a view to creating more opportunities for corruption, rather than to remedying inefficiencies. Therefore, increasing the salaries of officials is not a remedy for corruption because there is no risk of being caught, since higher officials are also corrupt, and, therefore, don't seek to enforce rules. Higher officials establish monitoring mechanisms only for symbolic reasons and not substantive control, and, therefore, create network externalities of participating in this corrupt environment.

The analysis of the 'network economy' theory described in Section 2 may explain the following characteristics of corruption:

First, as corruption is wide spread the risk of being captured in illegal activity decrease, both because the network of uncorrupt officials is smaller as well as the burden of dealing with too many corrupt officials is too discouraging.

In this framework I can add my personal experience. During a special auditing, while serving as the Accountant General of State of Israel, the auditors found that most of the thousands of patents that were invented by civil servants in the Ministry of Health (and according to law belong to the state and not to the employees) were registered under employee's name. In some cases the patents were registered under family members of the employees in order to hide the theft. The numbers of employees involved were tremendous: hundreds of them including seniors. When the State Chancellor at the Attorney General's office was approached by the matter he refused to cooperate with the Accountant General's office in their attempt to have the patents back. His refusal was justified by the rhetoric question: What do you expect of me? Press charges against the entire Ministry of Health? (See in more details Zelekha, 2012; Zeleka, 2013).

Second, as corruption is wide spread the options for cooperation and introducing additional opportunities for corruption increases.

A well-known claim in the literature describes an honest man nominated into a corrupt government office. Since the network value is affected by the volume of the participants in the network than his presence as honest non participant in the corruption network decreases its value and damaging the participants of the network. Therefore, even if this honest civil servant will not intervene in his colleagues illegal activities (and as a consequence will not expose them to risk of revealing the authorities) he will be subject to their encouragement to recruit him to the corruption network, or alternative to be expelled from office.

The network externalities can therefore explain the wide spread of the fixer's phenomenon (and the episodes in which fixers reach even informal control on a government institution) as well as the level of inefficient or corrupt government officials. Alternatively, if the supplier does not manage to reach a critical mass of customers on either side of the platform, he is destined to disappear. A classic example of a product that successfully exploited the characteristics of a network economy is the fax machine. The first users of the fax machine gained little benefit from the invention since there were few people to send faxes to. As the number of users grew, the value of the fax machine to the customer grew, as did the incentive for additional consumers to become fax users. A trendier example can be the use of Facebook.

The economic literature discusses three channels for the increase in utility that results from a growing network:

a. The effect on the new customer- an improvement in the utility of the customer as a result of access to customers who joined the network previously.

b. The effect on existing customers- an improvement in the utility of existing customers as a result of access to the new customer.

c. The effect on future/potential customers- the attractiveness of the network-both with respect to itself and with respect to its competitors - to potential customers grows with the number of customers in 
the network. As a result, the supplier's negotiating power with respect to his potential customers grows and at the same time the barrier to entry faced by new suppliers who have not yet built up a sufficient network of customers becomes increasingly difficult to penetrate. This channel is called a network externality and is of course negative.

Therefore, as corruption increases in scope, its continued growth and increasing power become more likely.

It should be mentioned, the claims that corruption may contribute to economic activity by speeding governmental processes tend to overlook the negative effects of direct network externalities, even though they are probably the main effects. Indeed, Mauro (2002) shows that countries tend to one of two stable equilibriums over time: a high level of income and a low level of corruption or a low level of income and a high level of corruption. The phenomenon of two extreme equilibriums is an expected outcome of the critical mass characteristics of network economy, which was described earlier.

Finally, the difference - between traditional networks competition and corrupt and non - corrupt network competition - should be stressed. While the traditional competition can resolve in a stable status quo of market shares among multiple networks (for example 3 and even 4 cellular network operators in most of the western markets with limited competition after reaching maturity in cellular penetration rates) the competition between corrupt and non - corrupt network has to resolved either way, or by mass distribution of the non - corrupt network or by mass distribution of the corrupt network. The difference between these opposite outcome of networks competition is a result of the difference between the possibilities of co-existence of the competing networks.

Regarding the traditional networks, they can co-exist and even have advantages from the existence of the rival network and the inter dynamics between them. For example, in the cellular market, the existence of multiple networks allows all of them to charge high interconnect tariffs, which were not possible at all if only one network would have prevailed. Furthermore, the rival networks help each other by educating the market to use the services and help reach high market penetration rates. When reaching maturity of the market, the competition is limited to the consumers which the cost of acquire them from the rival network is lower from the revenue from them.

Regarding the corrupt and non - corrupt networks, they can not create advantages from inter dynamics between them. Quiet the contrary. As explained, as the non - corrupt network expand the risk of being exposed as a member of the corrupt network expands.

In this framework I can add one more time from my experience as the Israeli Accountant General. We made thorough audits in order to check each and every wage contract to make sure it was legal, whether the wage level was according to the government wage table and whether proper taxes were being paid. One of the audits was implemented in a government unit that was located $30 \mathrm{Km}$ from Jerusalem, were most of the government units are located. It was found out that all (without any exceptions) of the unit's employees, including the Director General, were reporting few times a week, in certain fixed days, of work outside of office during lunch time, which entitled them for return of expenses for lunch without invoice and therefore increased their salaries significantly. Since it was very hard to believe that the entire over hundred employees has outside work simultaneity the auditors made some investigation and found that during the 1980's the government introduced fax machines. Therefore the need for the unit's employees to travel to Jerusalem (couple times a week for meetings, post-delivery etc.) stopped to exist and their salaries were hit by the absence of the return of lunch expenses. As a result they decided to compensate themselves by reporting false travels to Jerusalem. Each and every one, including dozens of new employees during the three decades until the audit caught them. Off course, this odd corrupt behavior was stopped but no charges were pressed against any one. It's not possible to charge hundreds of people involved during the years, not to mention their ability to justify themselves with the simple truth: Every one including management knew, approved and participated.

There are many more examples like that (including an audit at the Israeli Tax Authorities that revealed that perks being paid without proper tax deduction while trying to full the auditors) which will support the vast control of the corrupt network when it prevails (see Zelekha, 2008). Maybe the most appropriate example will be of the Minister who was nominated into a small government office and succeeded in a short period of time to nominate illegal few dozens of political allays into an office of about two hundred employees only. Every new political employee improved the ability to hire more and more political allays by creating additional opportunities. In court the Minister found innocent of criminal offence by defending himself that everyone done the same so he couldn't know it is illegal to transform a public office into a vehicle of recruiting political allays.

This outcome presents both two elements of corruption which is explained in network theory. First, as corruption 
is wide spread the risk of being captured in illegal activity decrease and second, as corruption is wide spread the options for cooperation and introducing additional opportunities for corruption increases.

On the other hand, it shloud be mentioned that Garson (2007), claims that the choice is not only between the two models of benevolent principal/corrupt agent and corrupt principal/corrupt agent. In systems marked by separation of powers and/or decentralization of powers, it is possible that some principals will be benevolent and others corrupt. Separation of powers, decentralization, and transparency in government measures can mitigate corruption. However, such measures only work to the extent that power is shifted from corrupt to benevolent principals. For instance, decentralization to local levels may shift power to more democratically accountable and benevolent principals or to more corrupt principals heavily under the control of local interests. Moreover, decentralization of spending decisions while continuing central control of revenue collection is likely to increase corruption, since the interests of central principals and local agents will diverge more sharply.

In this regard, the issue of corruption and fear should also be stressed. When people are afraid not to be part of the corrupt network, they can not continue their normal lives without being part of the network, and they either actively or passively join the corrupt network, or at least do not stand in its way. The political nominations is a good example, since the illegal nominations where done bluntly in front of internal auditor, internal comptroller and the legal advisor, which were all being afraid to create obstacles and prevent the nominations.

Therefore, Zelekha and Bar-Efrat following Mauro also claims that the extremes of the two possible equilibriums push countries toward one of two stable equilibriums over time: a high level of income and a low level of corruption, or a low level of income and a high level of corruption. The phenomenon of two extreme equilibriums is an expected outcome of the critical mass characteristics of network economy, which was described earlier. Unfortunately, it is thus almost impossible for a country to make transition on its own and the chances of gradual reforms are generally not very good.

\section{Concluding Remarks}

As we have seen, corruption has the characteristics of a network economy, meaning that as corruption increases in scope, its continued growth and increasing power become more likely.

In this regard, it seems that a major damage of corruption, and perhaps the most salient, is the lack of trust in others and in the system. Any system, including one that is governed by contracts and courts, ultimately needs the trust of the public within it. When the corruption level reaches the critical mass, the public loses its trust in the system as a whole, which creates a significant threat to the government's ability to rule as well as to entire democratic institutions and systems.

One also has to make a clear distinction between market power and corruption. The market system is only one way to allocate resources, and it is an efficient system when competition prevails and when there are no agents with market power or effective regulations governing the behavior of those with market power. Corruption prevents the market system from being efficient (even when no market power exists) and also prevents effective regulation.

These are perhaps the main reasons why corruption can cause such tremendous damage to the economy, and why research can explain a significant part of the difference in nations' wealth by the difference in corruption levels.

\section{References}

Bardhan, P. (1997). Corruption and Development: A Review of Issues. Journal of Economic Literature, 35, $1320-1346$.

Becker, G. S. (1968). Crime and Punishment: An Economic Approach. Journal of Political Economy, 76, 169-217. http://dx.doi.org/10.1086/259394

Ehrlich, I. (1973). Participation in Illegitimate Activities: A Theoretical and Empirical Investigation. Journal of Political Economy, 81, 521-565. http://dx.doi.org/10.1086/260058

Garson, D. (2007). Principal-Agent Theory. Retrieved from http//faculty.chass.ncsu.edu/garson/pa765/agent.htm

Macrae J. (1982). Underdevelopment and the Economics of Corruption: A Game Theory Approach. World Development, 10(8), 677-687. http://dx.doi.org/10.1016/0305-750X(82)90093-6

Mauro, P. (2002). The Persistence of Corruption and Slow Economic Growth. International Monetary Fund Working Paper, 02/213.

Rose-Ackerman, S. (1997). The Role of the World Bank in Controlling Corruption. Law and Policy in International Business, 29, 93-114. 
Shleifer, A., \& Vishny, R. W. (1998). The Grabbing Hand, Government Pathologies and their Cures. Cambridge, MA: Harvard University Press.

Stigler, G. J. (1970). The Optimum Enforcement of Laws. Journal of Political Economy, 78, 526-536. http://dx.doi.org/10.1086/259646

Zelekha, Y. (2008). The Black Guard, Kinneret-Zmora-Bitan Publishers (Hebrew).

Zelekha, Y. (2012). Fiscal Inefficiency, Corruption and Growth - The Israeli Case Study. The Cornell Policy Review, 2(2), 53-68.

Zelekha, Y. (2013). The Macroeconomics of Corruption. Ono Academic College Publishers. Forthcoming.

Zelekha, Y., \& Bar-Efrat, O. (2011). Crime, Terror and Corruption and their Effect on Private Investment in Israel. Open Economies Review, 22(4), 635-648.

\section{Copyrights}

Copyright for this article is retained by the author(s), with first publication rights granted to the journal.

This is an open-access article distributed under the terms and conditions of the Creative Commons Attribution license (http://creativecommons.org/licenses/by/3.0/). 